\title{
Characterization and origin of black and red Magdalenian pigments from Grottes de la Garenne (Vallée moyenne de la Creuse-France) : A mineralogical and geochemical approach of the study of prehistorical paintings
}

Pierre JEZEQUEL ${ }^{1}$, Guillaume WILLE ${ }^{1 *}$, Claire BENY ${ }^{1}$, Fabian DELORME ${ }^{1}$, Veronique JEAN-PROST ${ }^{1}$, Roger COTTIER ${ }^{1}$, Jean BRETON ${ }^{1}$, Frederic DURE ${ }^{1}$, Jacky DESPRIEE $^{2}$

${ }^{1}$ BRGM, MMA, 3, Avenue Claude Guillemin, BP 36009, 45060 ORLEANS Cedex 2, France.

* : corresponding author. Tel. : +33-2-38-64-35.22 ; Fax : +33-2-38-64-36-78 ; E-mail : g.wille@brgm.fr.

${ }^{2}$ UMR 5198, CNRS-MNHN, Departement de Prehistoire du Museum National d'Histoire Naturelle de Paris, Institut de Paleontologie Humaine, 1 rue Rene Panhard, 75013 PARIS, France.

\section{Abstract}

Pigments sampled from wall paintings and from crayons taken on the floor, at the Grottes de la Garenne (Saint-Marcel - Indre, France) have been analyzed and characterized by infrared spectroscopy, Raman micro-spectroscopy, X-ray diffraction, ICP/MS and analytical TEM. The red pigment used for the wall paintings is mainly composed by hematite, clays, carbon matter and carbonates. Results on the red pigments show that the compositions of the paintings are similar to that of some crayons.

Regarding these analyses, their origin is compatible with local siderolithic facieses. Analysis of black pigments shows that they are made of cryptomelane, pyrolusite, clays, carbonates and carbon matter. It shows also that paintings and some crayons compositions are compatible. On the contrary of red pigments, the origin of black pigments is probably allochtonous. Indeed, the traces of thallium detected in cryptomelane, the cerium anomaly and the absence of iron are not compatible with local facieses or other sites from the French Massif Central. 


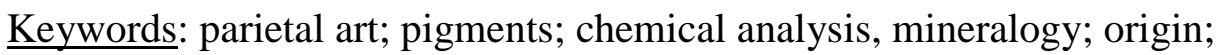

\section{Introduction}

35000 years ago, prehistorical men gave the first major art forms, stones or bones bearing simple incisions, followed by schematic geometrical and animals figures. Time after time, this prehistorical art is becoming increasingly sophisticated and precise to achieve the exceptional quality of wall paintings such as Lascaux cave paintings. This parietal art has been extensively studied by archaeologists, but inputs of sciences like chemistry, biology or geology can be fruitful for several reasons. Numerous studies have been conducted on paintings to understand the nature of the materials and for the understanding of the techniques used by prehistoric men. Thus different authors have used various analytical techniques to analyze prehistorical paintings such as optical microscopy, SEM-EDS (Garate et al., 2004; Chalmin et al., 2002; Chalmin et al., 2004a; Chalmin et al., 2006; Vignaud et al., 2006), Gas-Chromatography coupled to Mass spectroscopy (GCMS) (Pepe et al., 1991), TEM-EDS (Chalmin et al., 2004a; Chalmin et al., 2006), X-Ray diffraction (XRD) (Chalmin et al., 2006; Vignaud et al., 2006), IRTF and Raman spectroscopies (Van Der Weerd et al., 2004; Edwards and Newton, 2000), synchrotron radiation spectroscopies (XANES, EXAFS, XRF) (Chalmin et al., 2006; Reiche and Chalmin, 2008; Farges et al., 2005). Some authors have tried to determine how prehistorical men prepared and used these pigments, and they suggested for example that red pigments can sometimes be obtained by dehydrating goethite to transform it into hematite (Chalmin et al., 2004b; Pomies et al., 1998; Pomies et al., 1999). In contrast, no thermal treatments have been detected on black pigments obtained from manganese-based minerals (Chalmin et al., 2004b). 
The Grottes de la Garenne, located at Saint-Marcel, Indre - France (Figure 1) are a set of Magdalenian living sites (Despriee et al., 2001). These caves take place in a karstic context, belonging to an entrocs-containing bajocian limestone level that overlooks the river Creuse valley. The caves are located on the southern shore of the river Creuse, in a hill called Coteau de la Garenne. Known prehistoric sites are located on the west part of the hill. The first parts of this site have been discovered in 1848, during the building of the Paris - Toulouse railway. Several caves have been opened since this date. This site is a set of 9 archaeological levels, opened in the middle of the hill, at an altitude of approximately $120 \mathrm{~m}$. These levels seem to be a succession of spaces, living places and other places, successively occupied from the bottom to the top of the hill. The different levels have been dated $\left({ }^{14} \mathrm{C}\right.$ dating) from 15290 BP to 11920 BP (Despriee et al., 2001). Some of these places are sometimes well equipped (flooring, fireplaces...). An important set of objects has been discovered in the different levels, such as tools made with reindeer antlers, animals bones (reindeers, horses, wolves, rodents or fishes). The analysis of pollens and animals remains shows that this period corresponds to a cold steppes climate.

The walls of these caves are covered by a substantial set of paintings whose study may allow archaeologists to obtain information or confirm hypothesis about the techniques and tools used by men from the Magdalenian age (Vignaud et al., 2006). The study of these paintings can also be used to link painting materials to local or external supply sources. Several objects that could have been used as "crayons" have been found on the floor during explorations of the caves. Moreover, the answers obtain from this study can help to understand the risk of degradation of prehistorical painted caves like Lascaux cave (Allemand, 2003), Gargas cave (Mangin et al., 1999) or Arcy-Sur-Cure cave 
(Chalmin et al, 2008). A study of pigments samples taken on the prehistoric site of the Coteau de la Garenne at St Marcel allowed us to determine the nature of the main pigments listed during exploration of the Grotte Blanchard. The Grotte Blanchard has been discovered in 1956 by J. Allain during Grand Abri exploration. It opens in the South of the hill, a few tens of meters above the Creuse River. The cave is a small cavity of $4 \times 3 \mathrm{~m}$. Engravings can be noticed on a part of the north-east wall, on a surface of $3 \times 1.5 \mathrm{~m}$. It consists in several V-shaped or multiple lines incisions. The north-west wall is partially covered by red and black paintings, on a surface of $0.7 \mathrm{x} 1$ $\mathrm{m}$, forming a set of geometrical shapes (rectangles, lines, U-shaped lines, spots) (Figure 2). This cave is protected from the outside, the only access being a metallic scale controlled by a concrete airlock. This cave looks fragile and unstable, with cracked walls. The railway line which passes a few meters down in the valley causes severe vibrations. This highly increases the risk of rocks falling and walls degradation. Moreover, evidences suggest that this cave has been reworked by human activity throughout the time (Despriee et al; 2001). The use of this set of elements from the Magdalenian period is therefore urgent to increase the knowledge of this prehistorical stage through archaeological studies and subsequent actions for heritage conservation. A synthesis of the different works conducted by several archaeologists since the discovery of the cave has been done by a research group directed by J. Despriee (DRAC Centre) (Despriee et al., 2001). This synthesis gives a large overview of the knowledge of the site during the Magdalenian period.

The aim of this study is to characterize the red and black pigments in order to determine if the crayons found on the floor of the cave are related to the wall paintings and also to determine the geological origin of the red and black pigments. 


\section{Materials and methods}

Red and black pigments of 2-3 $\mathrm{mm}^{3}$ volume have been collected by scraping (Figure 3 ) on the walls of the Grotte Blanchard using a scalpel. Wall fragments have been collected together with pigments then samples have been purified by manual sorting under binocular microscope in lab in order to remove carbonates and others particles from the wall of the cave. Samples which are supposed to have been used as crayons have been collected on the floor of the cave. More than 110 samples (paintings, crayons) have been studied (Jezequel, 2001). Samples have been ground to powder using a agate mortar.

Powder X-ray diffraction (XRD) patterns have been performed on a Siemens D 5000 diffractometer (Bragg-Brentano geometry, $\theta / \theta$ goniometer) using $\mathrm{Co}-\mathrm{K}_{\alpha}$ radiation $(\lambda=$ $0.178897 \mathrm{~nm}$ ) and operating at $40 \mathrm{kV}$ and $30 \mathrm{~mA}$ at room temperature. The scans have been recorded from 4 to $84^{\circ}(2 \theta)$ with a step of $0.02^{\circ}$ and a counting time of 1 s per step. Diagrams have been indexed using DIFFRAC ${ }^{\text {plus }}$ software and international database JCPDS. Samples have been deposited on a suitable support for XRD analysis. For samples in small quantity, powder has been dispersed in ethanol and then deposited on a glass slide.

Fourier-Transform Infrared spectroscopy spectra (FTIR) have been acquired using BRUKER EQUINOX IFS-55 equipped with a high energy source, a $\mathrm{KBr}$ separator and a DTGS detector. Spectral resolution is $4 \mathrm{~cm}^{-1}$. Transmission spectra have been acquired 
on samples compacted in $\mathrm{KBr}: 0.5$ - $2 \mathrm{mg}$ are mixed within $250 \mathrm{mg} \mathrm{KBr}$ and compacted during 2 min under a pressure of 10 tons. Spectra have been collected in the range of wavelength $4000-350 \mathrm{~cm}^{-1}$. A GOLDEN-GATE ATR (Attenuated Total Reflectance) accessory has been also used for spectra acquisitions. This kind of acquisition does not require specific sample preparation. Sample is plated against a diamond brazed with wolfram carbide through a sapphire anvil. The range $4000-550 \mathrm{~cm}^{-1}$ is explored. Scan number is 32 for FTIR transmission acquisition, and 20 scans for ATR acquisition.

Raman micro-spectroscopy analysis has been performed using a DILOR XY800 Raman spectrometer equipped with an OLYMPUS microscope. Excitation beam wavelength is $\lambda=514.5 \mathrm{~nm}$ and the laser output power vary from 10 to $50 \mathrm{~mW}$. Samples have been observed and analyzed using the x100 and the x50 ULWD (Ultra Long Working Distance) objectives. Acquisition times vary from 60 to 300 seconds.

The Transmission Electron Microscopy (TEM) observations have been realized at 120 kV [Philips CM120 coupled to an EDAX EDS spectrometer (Electron Dispersive X-ray Spectroscopy)]. The TEM samples were prepared by dispersing the powdered samples in alcohol by ultrasonic treatment, dropping them onto a porous carbon film supported on a copper grid, and then dried in air.

ICP/MS (Induction Coupling Plasma / Mass Spectroscopy) quantification analyses have been conducted using a THERMO-OPTEK system equipped with a high sensitivity interface. The samples are dissolved in a high purity acid, then the solution is heated at $7000{ }^{\circ} \mathrm{C}$ in the core of the argon plasma and analyzed by mass spectroscopy. 


\section{Results and discussions}

\subsection{Red pigments}

\subsubsection{Pigments from the Grottes de la Garenne - paintings and crayons}

As noticed by several authors in numerous Magdalenian caves (Chalmin et al., 2002; Pepe et al., 1991; Vignaud et al., 2006; Pomies et al., 1999), the main components identified by X-ray diffraction on red crayons are iron oxides (hematite $\mathrm{Fe}_{2} \mathrm{O}_{3}$ ) and hydroxides, gehlenite $\left(\mathrm{Ca}_{2} \mathrm{Al}_{2} \mathrm{SiO}_{7}\right)$, quartz and microcline $\left(\mathrm{KAlSi}_{3} \mathrm{O}_{8}\right)$ (Figure 4). Evidence of one or several amorphous phases is shown by XRD. The same composition has been noticed for the paintings pigments. Presence of carbonates in higher quantities in crayons than in paints can be highlighted by FTIR (bands at 1430, 877 and $713 \mathrm{~cm}^{-1}$ ). It shows that several types of crayons are presents (Figure 5). Furthermore, the detritic origin of hematite is confirmed by its hydration and its association to a clay fraction (kaolinite, FTIR bands at 3696 and $3622 \mathrm{~cm}^{-1}$ ) and to gehlenite.

The presence of carbon matter in the paint is noticed by ATR-FTIR peaks at 2963, $2930,2860 \mathrm{~cm}^{-1}$ in the wall paintings, but not in the crayons themselves (Figure 5). It could suggest that a mixture has been used rather than pure natural ore. Occurrence of a sub-layer of carbon matter before painting, or variations in the composition of the natural or manufactured crayons could be other hypotheses. Several authors have studied the techniques of the artists of the Magdalenian period and the use of organic matter and / or charcoal has already been reported (Chalmin et al., 2004a; Menu and Walter, 1996, Pepe et al., 1991). 
The ICP/MS characterization of trace elements, especially Rare Earth Elements (REE), confirms that pigments from paints and from crayons have the same origin, their REE compositions being similar (Figure 6).

\subsubsection{Study of the local sites with a compatible iron index}

Iron-based minerals have been extensively studied in the area around Argenton/Creuse and reported in numerous publications (De Grossouvre, 1886; BRGM 1998; Laut, 1994; Dieudonne-Glad, 1991). Numerous works have been conducted at the $\mathrm{XIX}^{\text {th }}$ and $\mathrm{XX}^{\text {th }}$ centuries for iron minerals extraction (De Grossouvre, 1886; BRGM, 1998). The study of Gallo-roman iron manufacturing and use around Argenton/Creuse shows that some iron ore (especially the Chaillac ore, known for a specific manganese and barium concentration) have been manufactured sometimes more than $30 \mathrm{~km}$ around there extraction site (Laut, 1994; Dieudonne-Glad, 1991).

Possible extraction sites around La Garenne have been selected by crossing literature data (De Grossouvre, 1886; BRGM 1998; Laut, 1994; Dieudonne-Glad, 1991) and geological maps (Geological maps 1/50 $000 \mathrm{n}^{\circ} 592$, 569, 570, 593 - BRGM). 23 sites have been selected by geological criteria and sampled for comparison with the red pigments from La Garenne. A schematic repartition of the sampling sites is shown on Figure 7.

These samples have been studied by XRD (mineral composition) and ICP/MS (REE composition). The mineral composition of the samples from local sites are similar to the composition of the red pigments (XRD pattern not shown) and clearly suggests a local origin of the red pigments. The study shows that the origin of the red pigments has to be 
found in ferruginous oolites emplaced in old alluvial deposits over the right bank of the river Creuse, in an area close to the cities of St Gaultier, Ciron, Scoury and Ruffec (Figure 7). Indeed, the efficiency of the hematite staining is much more important when associated with a clay fraction. A specific ICP/MS analysis of samples from a site upstream of the village of St Gaultier suggests that this site corresponds to the red pigments extraction site (Figure 8).

\subsection{Black pigments}

\subsubsection{Pigments from the Grottes de la Garenne - paintings and crayons}

Numerous studies on black pigments of Magdalenian paintings suggest that the most used black pigments are charcoal and manganese oxides (Chalmin et al., 2002; Chalmin et al., 2004a; Vignaud et al., 2006).

XRD study of black pigments shows that the samples from the Grotte Blanchard are made of several manganese-containing phases such as cryptomelane $\left(\mathrm{KMn}_{8} \mathrm{O}_{16}\right)$ and pyrolusite $\left(\mathrm{MnO}_{2}\right)$, and a little part of quartz (Figure 9). Infra-Red analyses also shows the presence of clays, carbonates and carbonaceous matter.

In addition, the main band of cryptomelane shows frequency variations ( 
Figure 11) on the Raman spectra (639 to $\left.643 \mathrm{~cm}^{-1}\right)$. These variations are probably related to composition variations of this mineral. Indeed, barium substitution of potassium in some cryptomelane crystallites is noticed in EDS-TEM analysis (Figure 12).

Chemical analysis results from ICP/MS for REE concentration are similar for pigments in the paintings and in some of the crayons and both present an anomaly for cerium (Figure 13). Another anomaly is also noticed for thallium $(0.15-0.20 \% \mathrm{Tl})$ both in the paint and in the crayons. TEM characterization of single grains allows demonstrating that $\mathrm{Tl}$ is systematically associated to cryptomelane (Figure 12).

Finally, it is possible to conclude that some crayons found in the caves could have been used to produce the black-colored parietal paintings, regarding the different FTIR, Raman, EDS-TEM and ICP/MS results.

\subsubsection{Study of local sites and sites from the French Massif Central with a compatible manganese index}

In order to identify the extraction sites of the black pigments, a sampling has been performed after a pre-selection of the most compatible Mn indexes in an area of 30-40 $\mathrm{km}$ around the caves, and extended to the French Massif Central. This selection was based on chemical and geological data, but also on archeometry data regarding the Magdalenian age in this area.

The study of the samples by EDS-TEM has shown that Tl is associated to cryptomelane in the crayons and the paintings. $\mathrm{Tl}$ is not found as an element of other parts of the 
pigments matter. The association $\mathrm{Mn}-\mathrm{Tl}$ is known since the 60's (Vlasov, 1964). It is related to a substitution $\mathrm{Mn}-\mathrm{Tl}$ in final hydrothermal phases. The presence of thallium in the pigments could indicate that the cryptomelane has been extracted from an ore coming from a late hydrothermal process. Moreover, this type of high oxidation degree - manganese ore is found in hydrothermal-type deposits, in hypogene veins, in vein fillings, or comes from the processing of the primary ore by supergene oxidation. It can be found as a residue in superficial ore.

16 sampling sites have been selected (Figure 14). Collected samples have been analyzed by EDS-SEM and ICP/MS and XRD. Local indexes of manganese reveal an association with iron and in a less extent barium. However, cave black pigments analyses do not reveal the presence of iron. This lack of iron, coupled to the presence of thallium, and the specificity of the REE spectra concentration profile (Figure 15, Table 1) indicate that probably no local ore can provide matter in good agreement with the pigments composition. Unlike for red pigments, it allows to conclude to an allochtonous origin: samples from the sampling sites have been analyzed and are not compatible with the black pigments. It is possible that the sampling area is too small and the hypothesis of a farthest supply site must be considered. Some mineralogical and geochemical investigations could be necessary towards the Atlantic (Poitou strait), the North (Morvan area) or even in a wider area (French Pyrenees, Spain ...).

The "non-local" origin of the black "manganese oxide-based" pigments has been reported by other authors in the pictorial materials of Magdalenian caves (Chalmin et al., 2002; Chalmin et al, 2006). 
However, the analysis of some of the crayons collected in the cave, that have not been used for the wall paintings, is compatible with one of the sampled sites (La Redoutiere Chaillac District, 30km from La Garenne). It shows that for these crayons manganese mineral could have been locally collected. New questions arise then: What was the use of these crayons as they were not used for the wall paintings, and why Magdalenian men did not use them to achieve the paintings of the Grotte Blanchard?

\section{Conclusion}

This study focused on the colors of the Grottes de la Garenne. It allowed us to determine the nature of the pigments and the variety of their origins.

Red pigments have been identified to be based on more or less hydrated hematite associated to a small part of clays (kaolinite), some different silicates (gehlenite, illitemicas...) and carbon matter. ICP/MS demonstrated that pigments from the paints and from the crayons have the same origin. It allowed showing that this pigment composition is compatible with local siderolithic facieses.

On the other hand, black pigments from paintings and some crayons are essentially made of manganese-containing phases, such as cryptomelane, pyrolusite, associated to a small part of quartz, phyllites, carbonates and carbon matter. The same origin of pigments from paints and some crayons has been established by ICP/MS analyses. However, unlike the red pigments, their origin is not compatible with local facieses. Indeed, an anomaly on cerium concentration, the presence of thallium, the trace or absence of iron are noticed in the pigments composition, while manganese is associated to iron and more or less barium in local indexes. Thallium-containing cryptomelane 
could indicate an ore coming from a late hydrothermal process, whose origin need to be determined. Extension of the sampling area to the all French Massif Central shows also no compatible facieses.

Besides, it could be useful to understand for which use was another type of black crayons whose origin has been locally discovered, and why these crayons have not been used for the paintings in the Grotte Blanchard. This case is not unique, we can cite works done in Lascaux, as an example (Chalmin et al, 2004a).

Finally, this works highlights the fact that a complete and precise geological approach is necessary for the identification of the nature and the supply sources of prehistorical paintings and pigments.

\section{Acknowledgements}

Pr Denis Vialou, Professor at the department of prehistory at the Museum National d'Histoire Naturelle (MNHM, Paris - France), is gratefully acknowledged for his help, especially for sampling the red and black pigments in the Grotte Blanchard.

This work has been funded by the DRAC Centre. 


\section{References}

Allemand L., Qui sauvera Lascaux, 2003, La Recherche, 363, 26-33 (in French)

BRGM, Geological maps 1/50 $000 n^{\circ}$ 592, 569, 570, 593 - BRGM Edition

BRGM, Inventaire minier du territoire national - DM Massif Central, (1974-1998), 1988 (in French)

Chalmin E., Menu M., Altuna J., Les matieres picturales de la grotte d'Ekain, 2002, Munibe 54, 35-51 (in French, with English abstract)

Chalmin E., Menu M., Pomies M.P., Vignaud C., Aujoulat N., Geneste J.M., Les blasons de Lascaux, 2004a, L'anthropologie, 108, 571-592 (in French, with English abstract)

Chalmin E., Vignaud C., Menu M., Paleolithic painting matter: natural or heat-treated pigments?, 2004b, Appl. Phys. A 79, 187-191

Chalmin E., Vignaud C., Salomon H., Farges F., Susini J., Menu M., Minerals discoveres in paleolithic black pigments by transmission electron microscopy and micro-X-ray absorption near-edge structure, 2006, Appl. Phys. A 83, 213-218

Chalmin E., Sansot E., Orial G., Bousta F., Reiche I., Microanalysis and synthesis of calcite. Growth mechanisms on prehistoric paintings in the Large Cave, Arcy-Sur-Cure (Yonne, France), 2008, X-ray Spectrom. 37, 424-434

De Grossouvre A., Etude sur les gisements de minerai de fer du centre de la France, 1886, Annale des Mines $8^{\mathrm{eme}}$ serie tome 10, 331-418 - DUNOD Edition (in French) Despriee J., Bulletin de l'association pour la sauvegarde du site archeologique d'Argentomagnus et Amis du Musee - Le Coteau de la garenne, collaborative research project 1999-2001, 2001 (in French)

Dieudonne-Glad N., La metallurgie du fer chez les bituriges à l'epoque gallo-romaine, Thesis, University Paris I, 1991 (in French)

Edwards H.G.M., Newton E.M., Russ J., Raman spectroscopic analysis of pigments and substrata in prehistoric rock art, 2000, J. Mol. Struc. 550-551, 245-256

Farges F., Chalmin E., Vignaud C., Pallot-Frossard I., Susini J., Bargar J., Brown Jr G.E., Menu M., Archeological applications of XAFS: prehistorical paintings and medieval glasses, 2005, Phys. Scr. 115, 885-887

Jezequel P., Etude minéralogique de 116 echantillons en provenance du site prehistorique du coteau de "La Garenne", St Marcel (Indre), 2001, BRGM report ANA/CMI/NT/01/154 
Garate D., Laval E., Menu M., Etude de la matiere colorante de la grotte d'Arenaza, 2004, L'anthropologie 108, 251-289 (in French, with English abstract)

Laut L., L'espace rural antique autour d'Argentomagus, Thesis, University Paris I, 1994 (in French)

Mangin A., Bourges F., D'Hulst D., La conservation des grottes ornees : un probleme de stabilite d'un systeme naturel (l'exemple de la grotte prehistorique de Gargas, Pyrenees francaises), 1999, C.R. Acad. Sci. Paris, Sciences de la terre et des planetes 328, 295 301 (in French, with English abstract)

Menu M., Walter P., Prehistoric cave painting PIXE analysis for the identification of paint "pots", 1992, Nuclear Instruments and Methods in Physics Research Section B: Beam Interactions with Materials and Atoms, 64, 547-552

Pepe C., Clottes J., Menu M., Walter P., Le liant des peintures paleolithiques ariegoises, C.R. Acad. Sci. Paris, 132 serie II (1991), 929-934 (in French, with English abstract) Pomies M.P., Menu M., Vignaud C., TEM observation of goethite dehydration: application to archaeological samples, 1999, J. European Ceramic Soc. 19, 1605-1614 Pomies M.P., Morin G., Vignaud C., XRD study of the goethite-hematite transformation: application to the identification of heated prehistoric pigments, 1998, Eur. J. Solid State Inog. Chem. 35, 9-25

Reiche I., Chalmin E., Synchrotron radiation and cultural heritage : combined XANES/XRF study at Mn-K-edge of blue, grey or black coloured palaeontological and archaeological bone material, 2008, J. Anal. At. Spectrom 23, 799-806

Robert J.C., Synthèse des études de valorisation effectuées sur le minerai de barytine de Chaillac (Indre), 1972, BRGM report n 72SGN297MIN (in french)

Van Der Weerd J., Smith G. D., Firth S., Clark R. J.H., Identification of black pigments on prehistoric Southwest American potsherds by infrared and Raman microscopy, 2004, J. Archeol. Sci. 31, 1429-1437

Vignaud C., Salomon H., Chalmin E., Geneste J.M., Menu M., Le groupe des "Bisons adosses" de Lascaux. Etude de la technique de l'artiste par analyse des pigments, 2006, L'anthropologie, 110, 482-499 (in French, with English abstract)

Vlasov K.A., Geochemistry, mineralogy and generic types of occurrences of the rare earth elements, 1964, Vol. II Mineralogy of rare earth elements, Nauka Publ. (Moscow) 


\section{Figures}

Figure 1 : Location of Saint-Marcel, France

Figure 2 : The Grand Abri and the Grotte Blanchard (Despriee, 2001)

Figure 3 : Red and black pigments on the wall of the Grotte Blanchard and sampling

Figure 4 : XRD on a red crayon (* Hematite; $\diamond$ Quartz; $\square$ Microcline; $\bullet$ Gehlenite)

Figure 5 : FTIR spectra - red pigments from the paint and a crayon

Figure 6 : rare earth elements concentration $(I C P / M S)$ in red pigments from the paintings (full square) and the crayon (empty square)

Figure 7 : map of the iron minerals sampling sites

Figure 8 : rare earth elements concentration (ICP/MS) of the iron-compatible samples collected close to St Gaultier

Figure $9:$ XRD on black pigments

Figure 10 : FTIR spectra of black pigments

Figure 11 : Raman analysis of black pigments

Figure 12 : EDS spectrum of a cryptomelane particle - Mn / Ba substitution

Figure 13 : Rare earth elements concentration in black pigments from the paint (Full Square) and the crayon (Empty Square)

Figure 14 : Map of the sampling sites around La Garenne for Mn ore identification

Figure 15 Rare earth elements concentration in black pigments from the pigments (dotted line) and Mn ores (see Table 1 for description)

\section{Tables}

Table 1 Black pigments and Mn ores samples from Figure 13-Description of samples from Figure 14 
Figure 1 : Location of Saint-Marcel, France

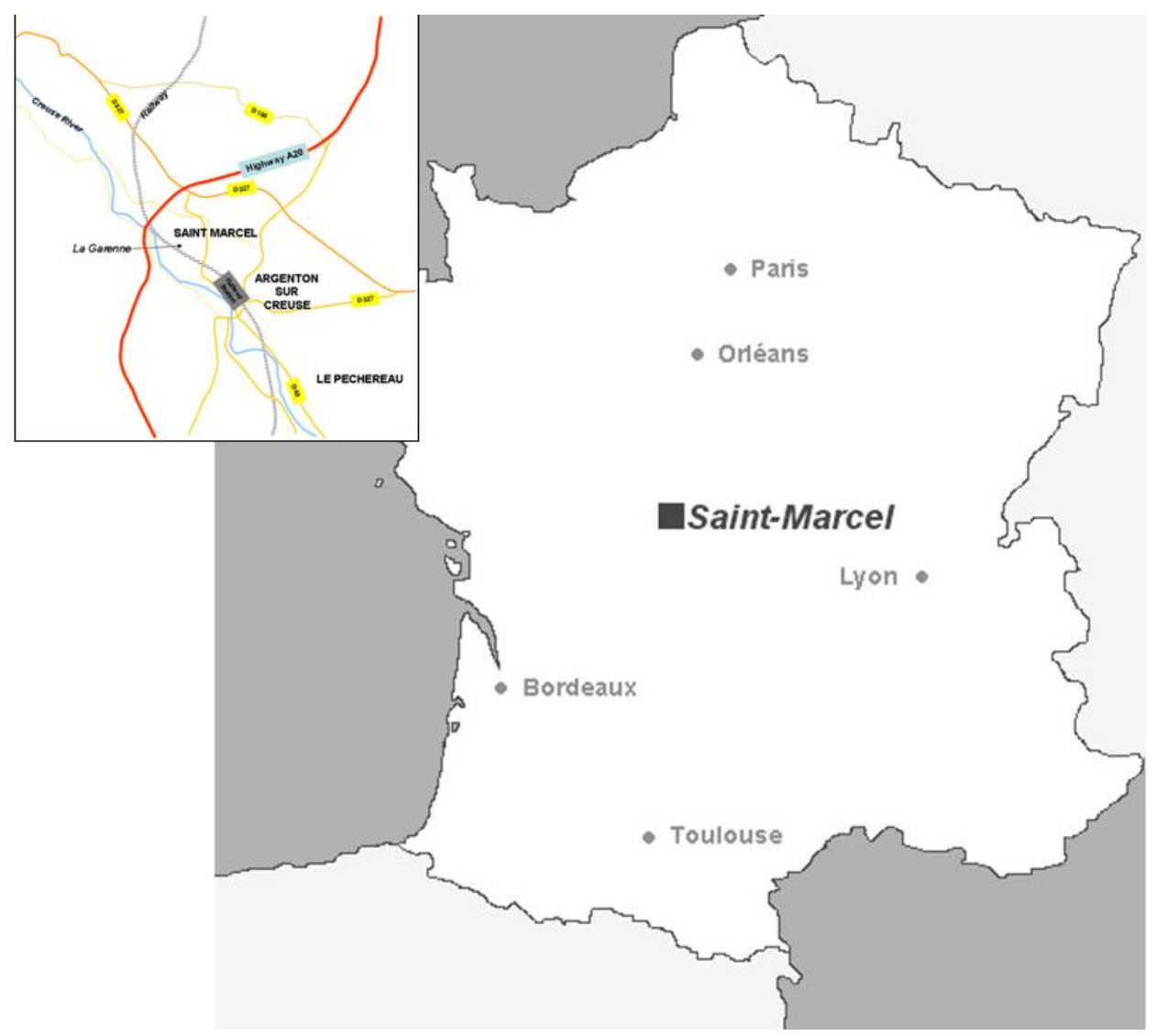


Figure 2 : The Grand Abri and the Grotte Blanchard (Despriee, 2001)

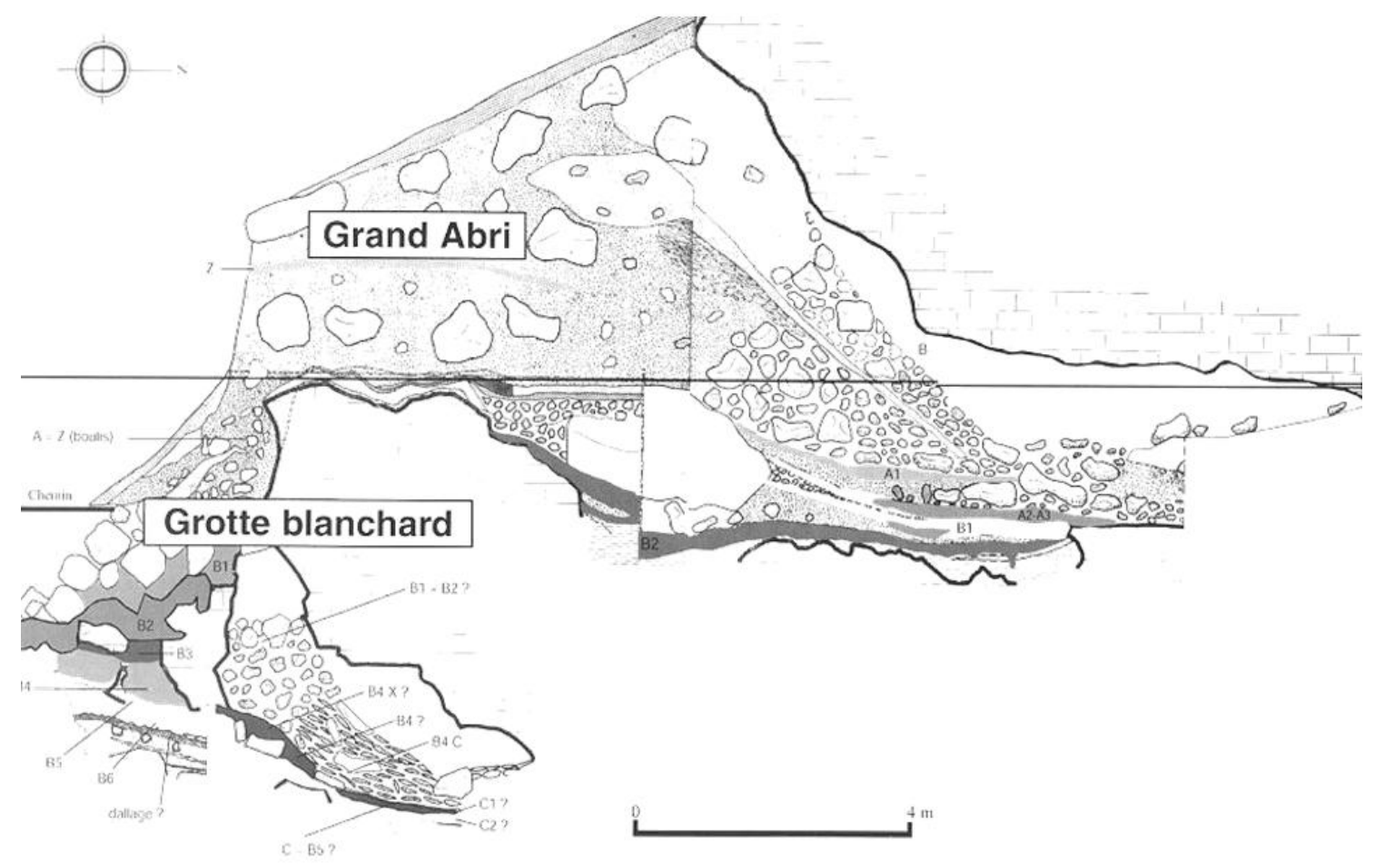

Red and black pigments on the wall of the Grotte Blanchard 
Figure 3 : Red and black pigments on the wall of the Grotte Blanchard and sampling

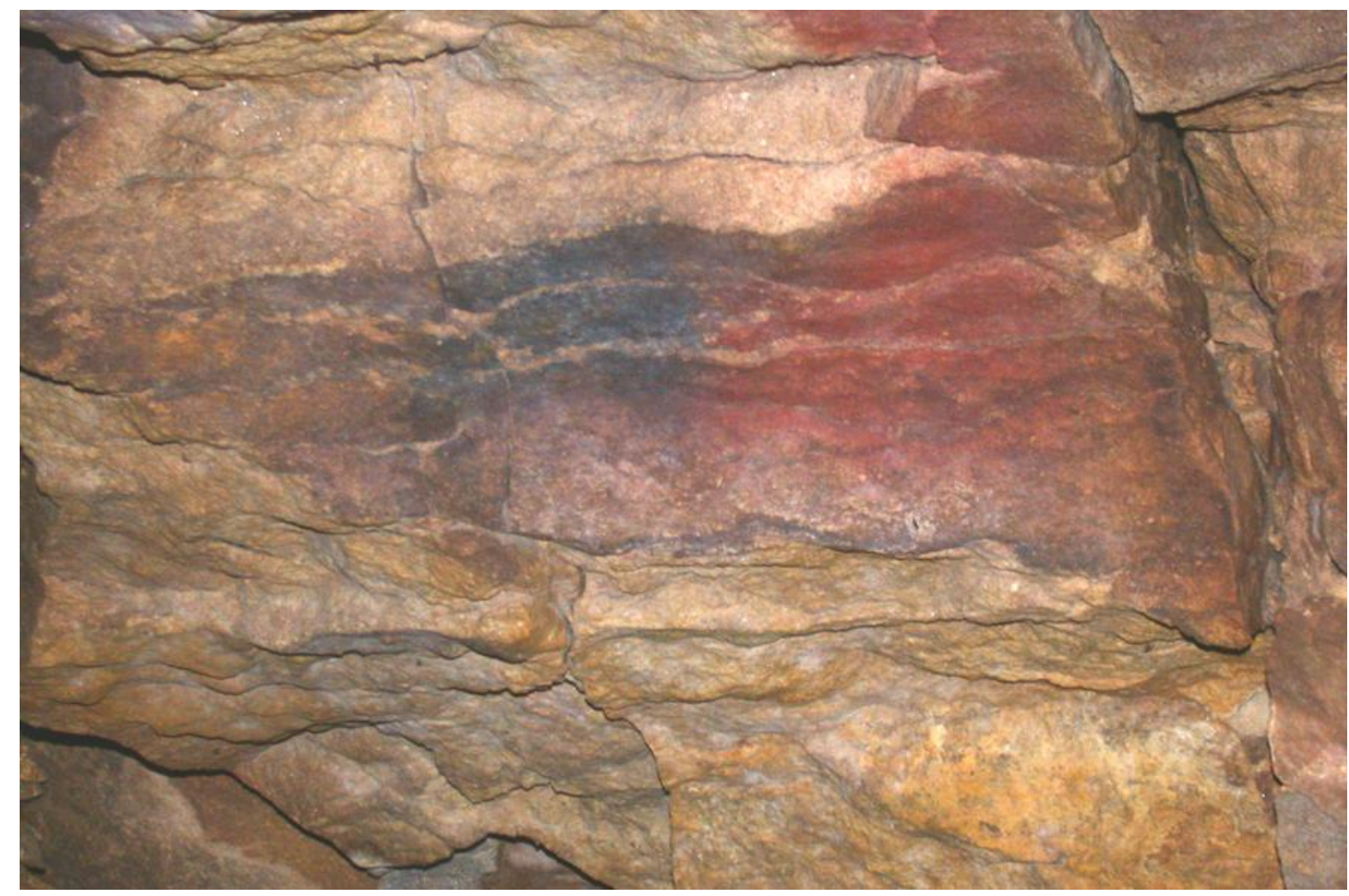


Figure $4:$ XRD on a red crayon $(*$ Hematite; $\diamond$ Quartz; $\square$ Microcline; $\bullet$ Gehlenite)

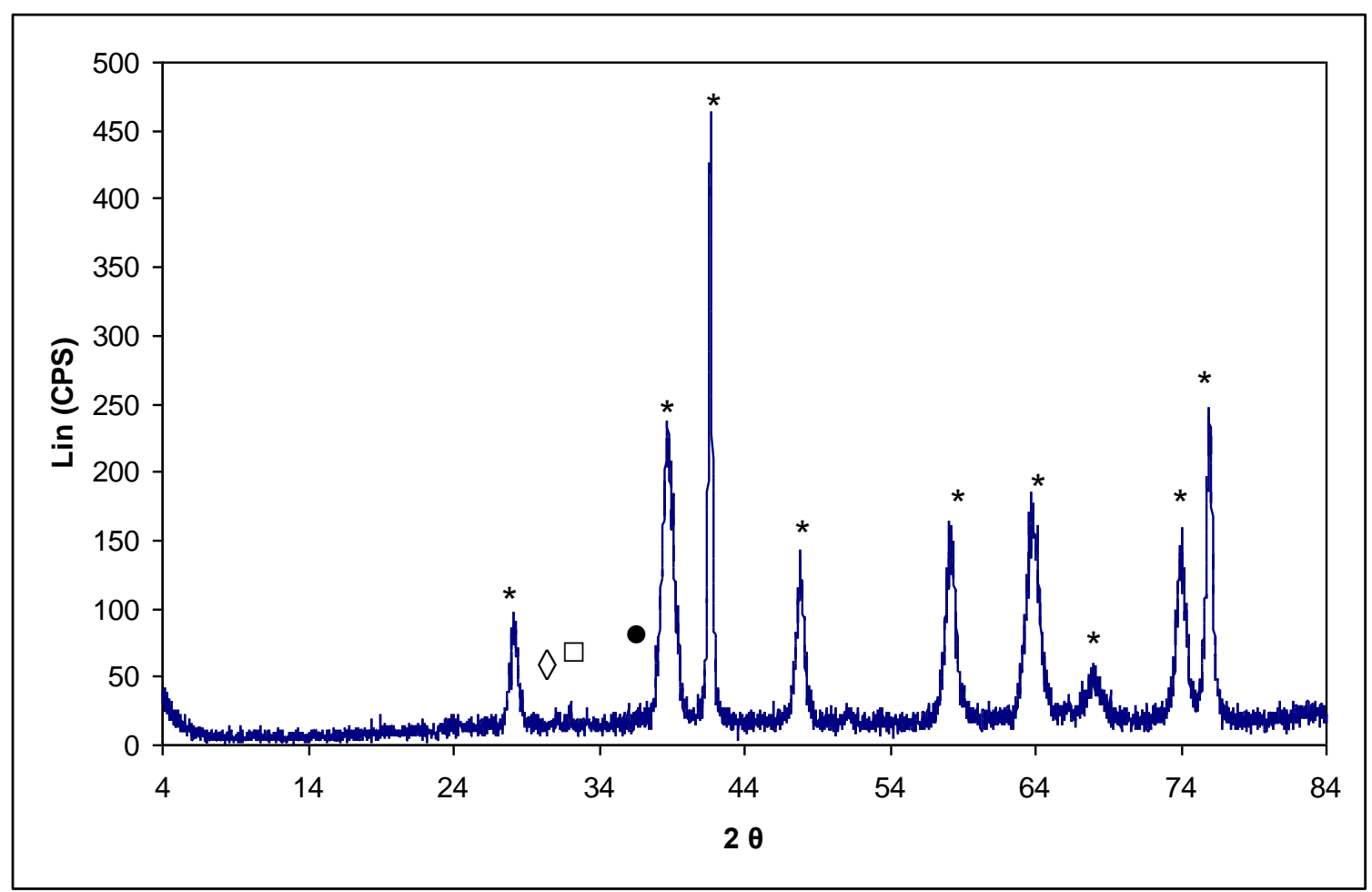


Figure 5 : FTIR spectra - red pigments from the paint and a crayon

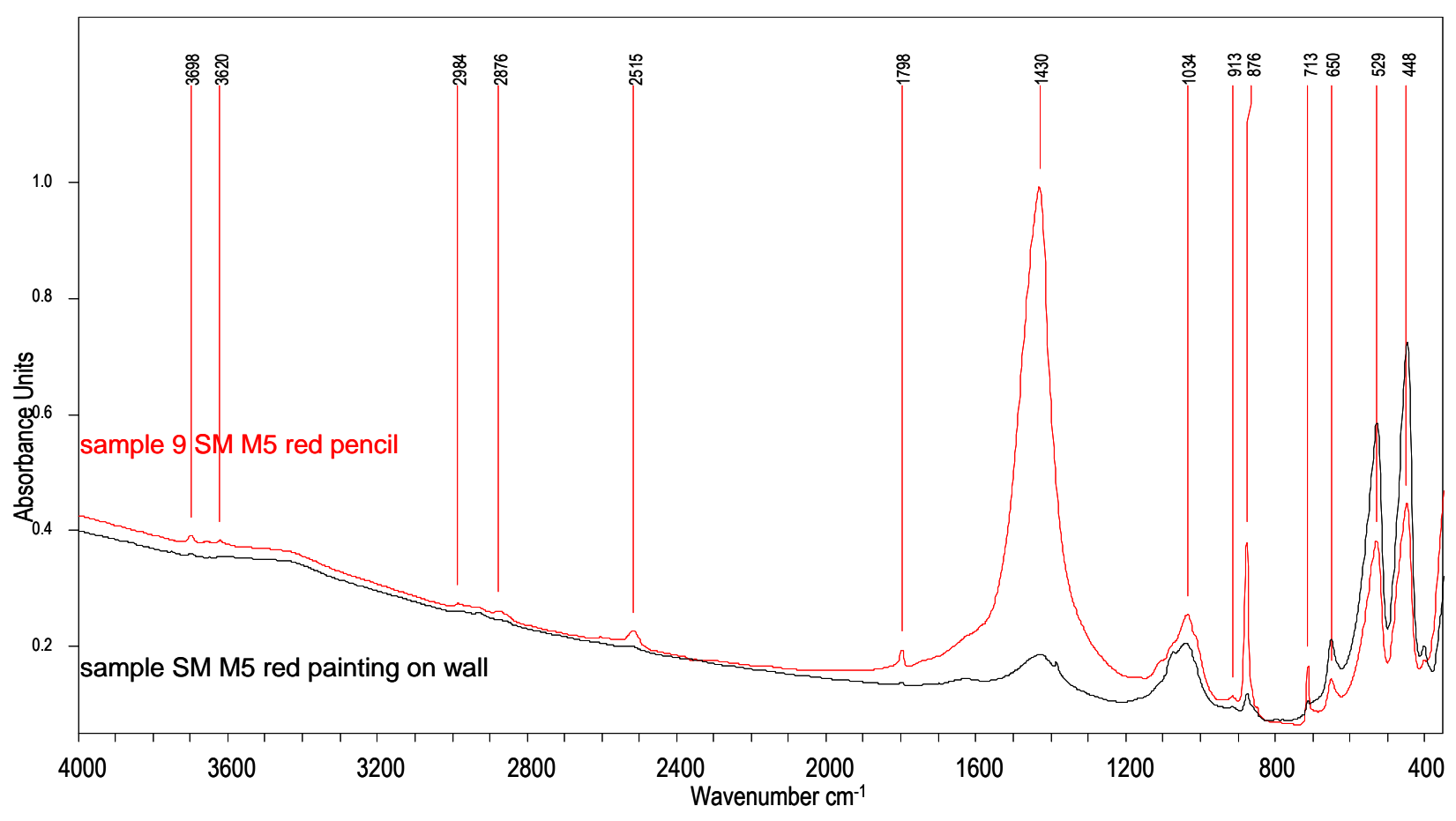


Figure 6 : rare earth elements concentration (ICP/MS) in red pigments from the paintings (full square) and the crayon (empty square)

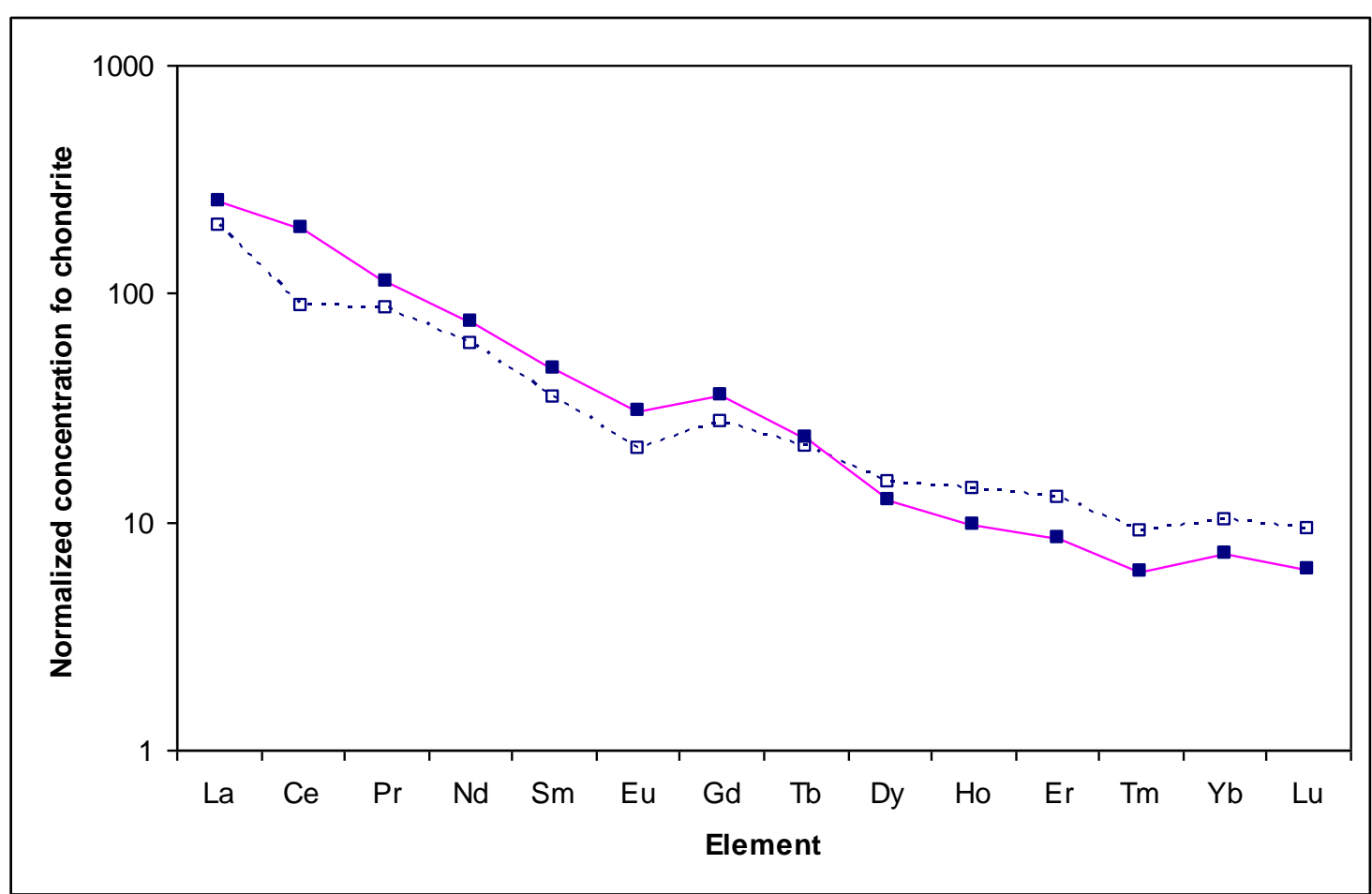


Figure 7 : map of the iron minerals sampling sites

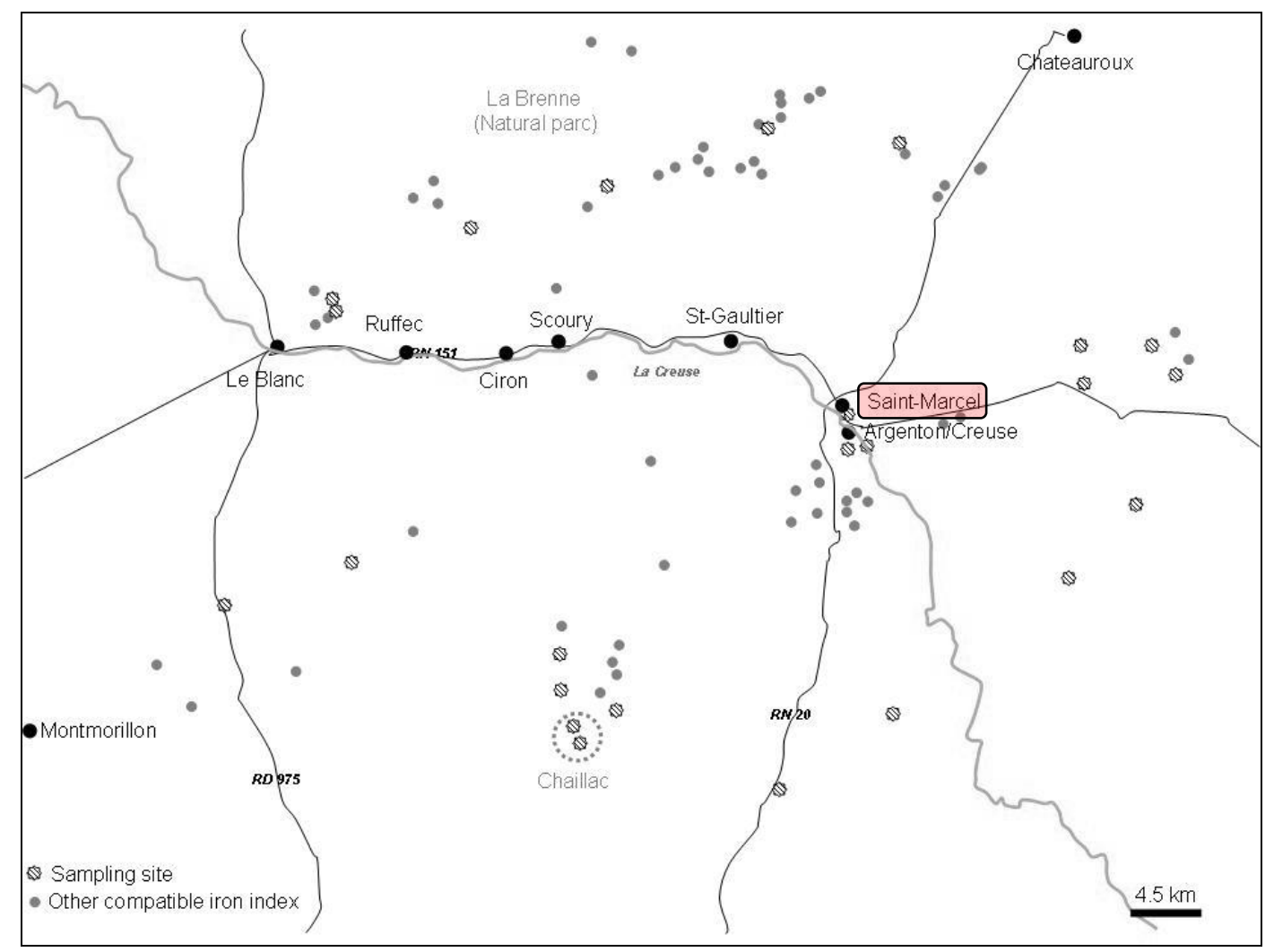


Figure 8 : rare earth elements concentration (ICP/MS) of the iron-compatible samples collected close to St Gaultier

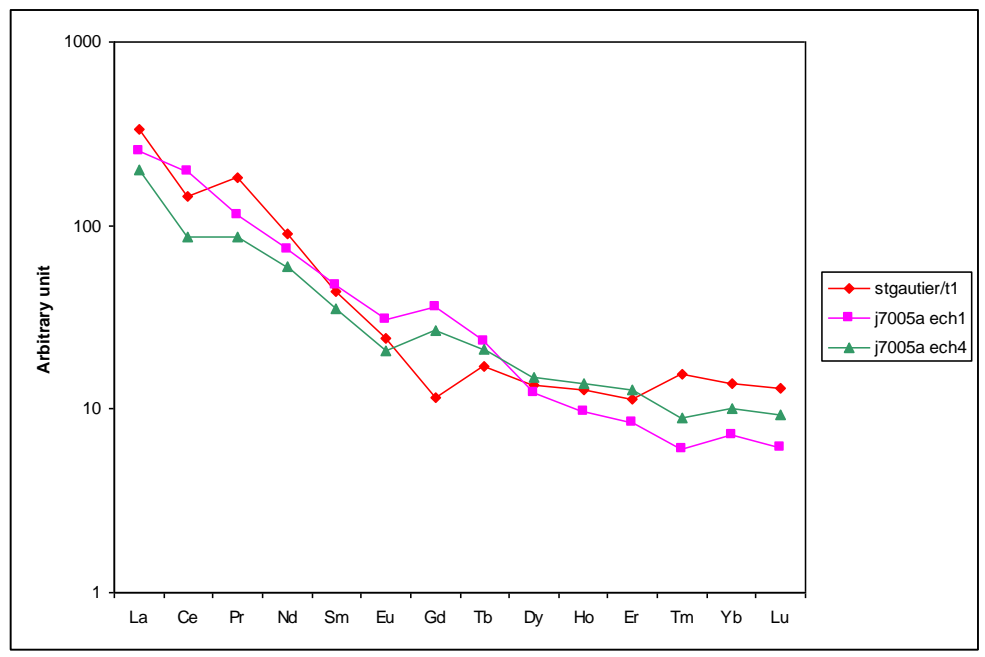


Figure 9 : XRD on black pigments (*Cryptomelane; $\bullet$ Pyrolusite, $\diamond$ Quartz)

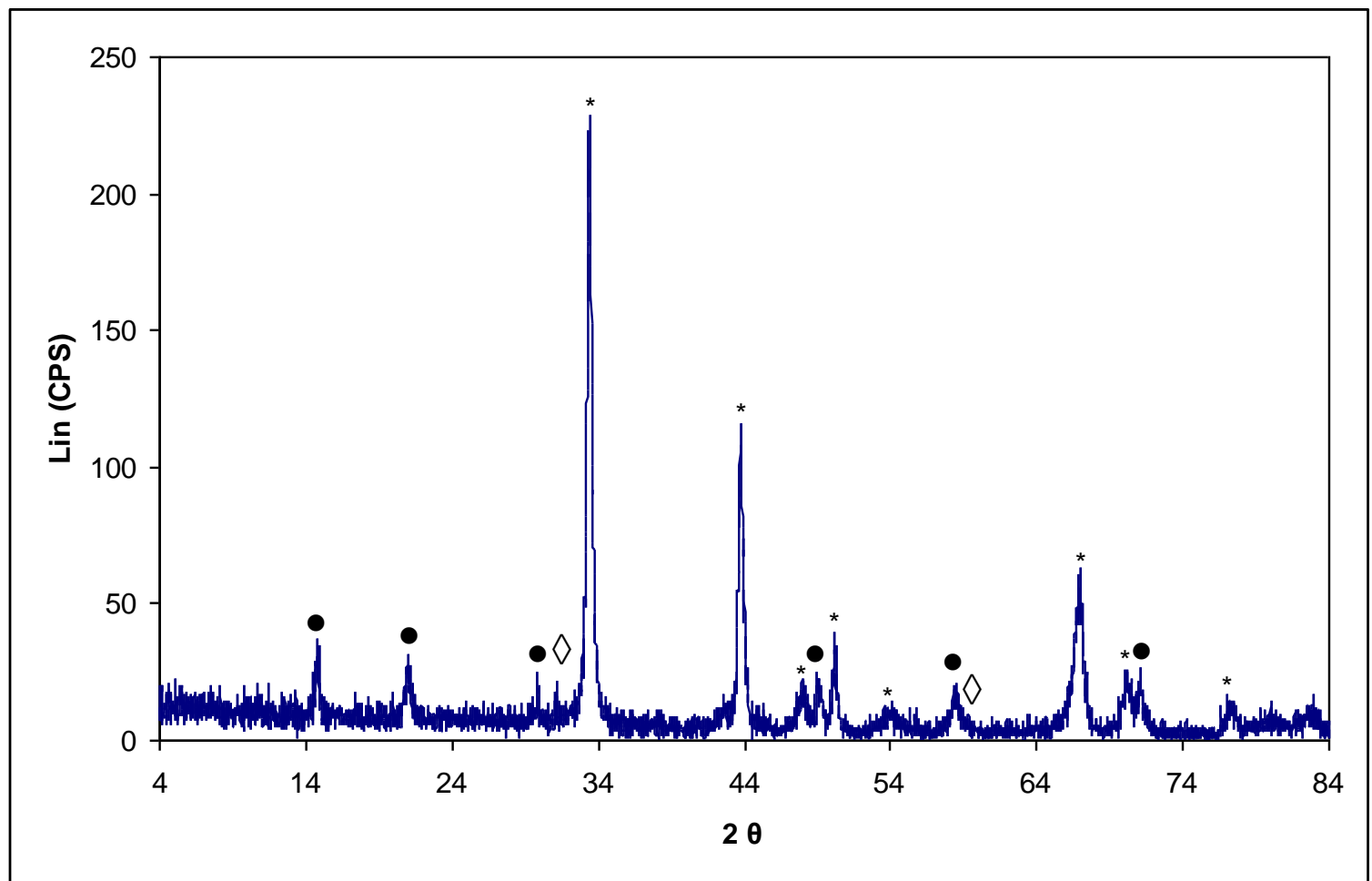


Figure 10 : FTIR spectra of black pigments

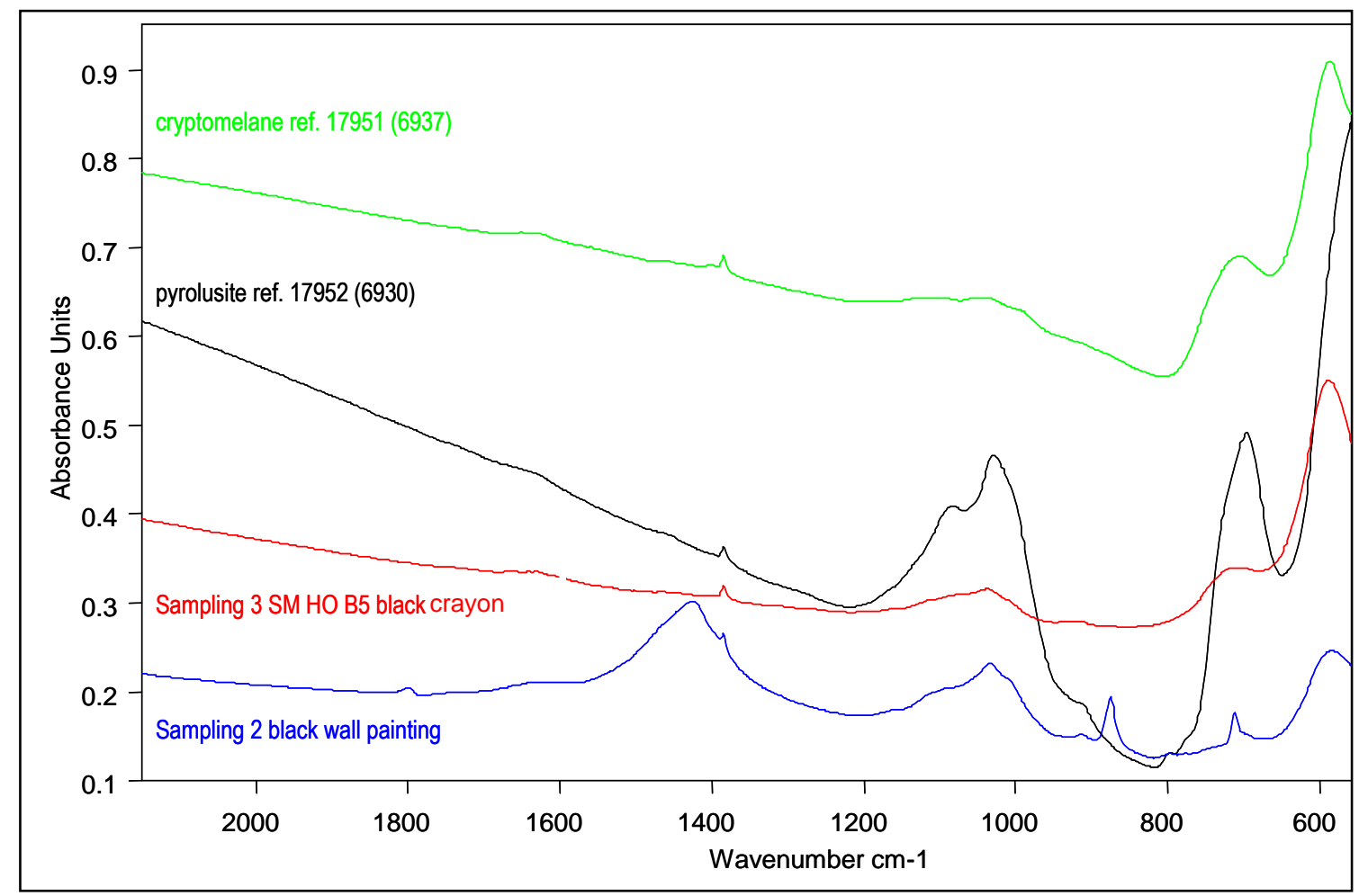


Figure 11 : Raman analysis of black pigments

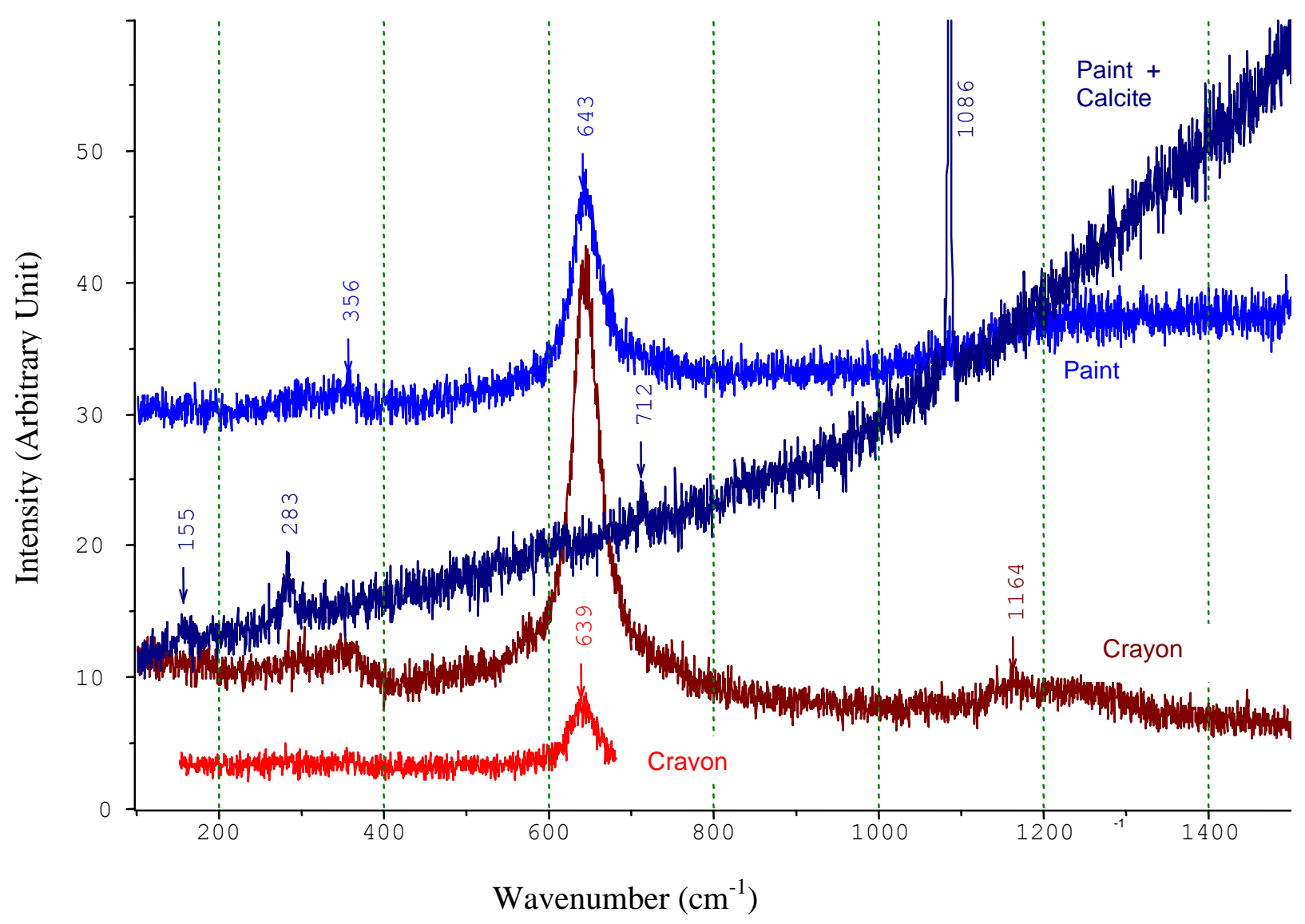


Figure 12 : EDS spectrum of a cryptomelane particle - Mn / Ba substitution

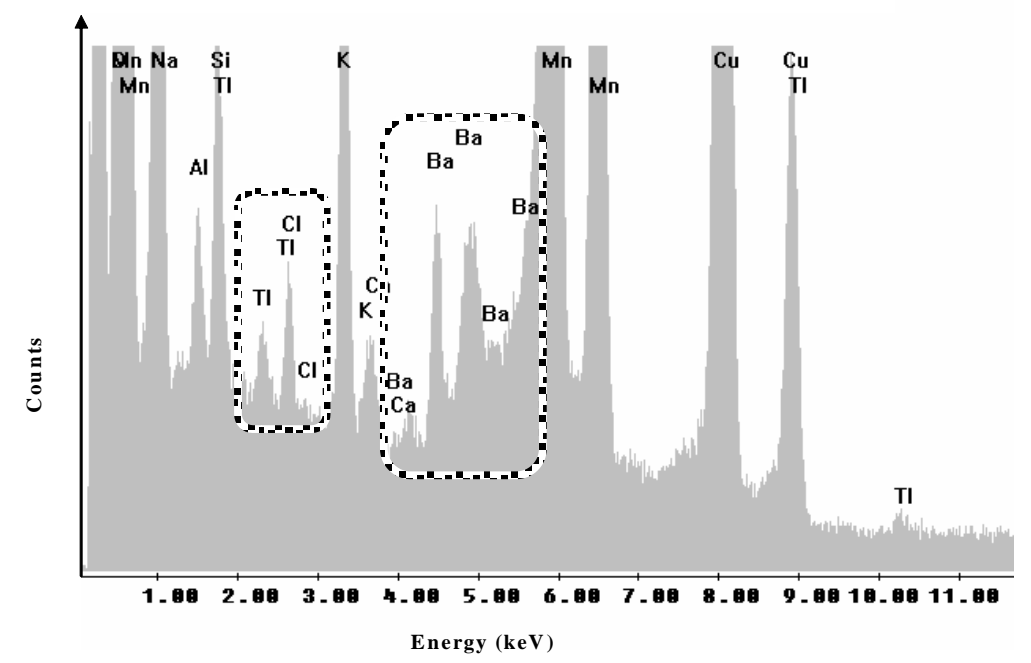


Figure 13 : Rare earth elements concentration in black pigments from the paint (Full Square) and the crayon (Empty Square)

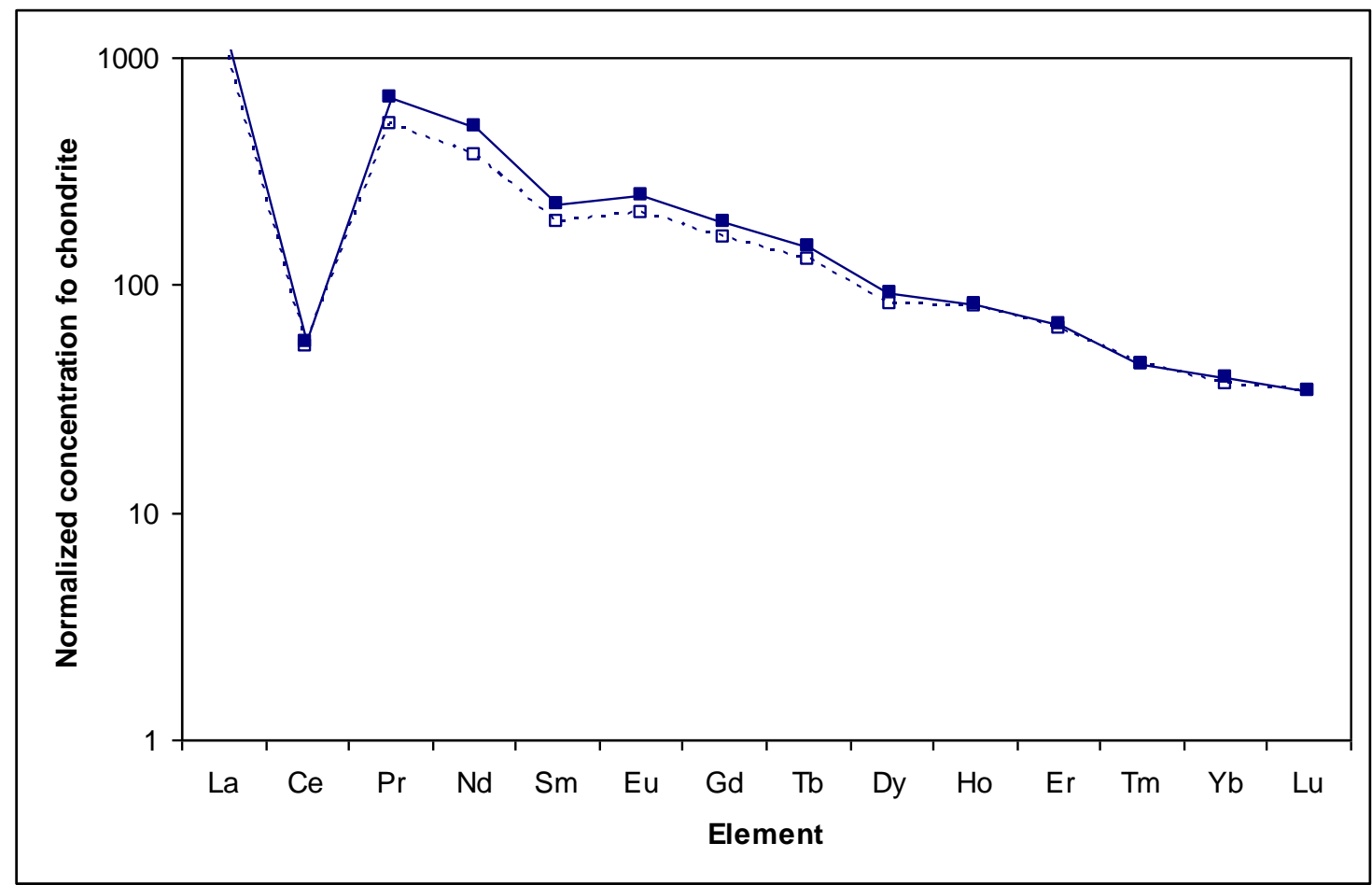


Figure 14 : Map of the sampling sites around La Garenne for Mn ore identification

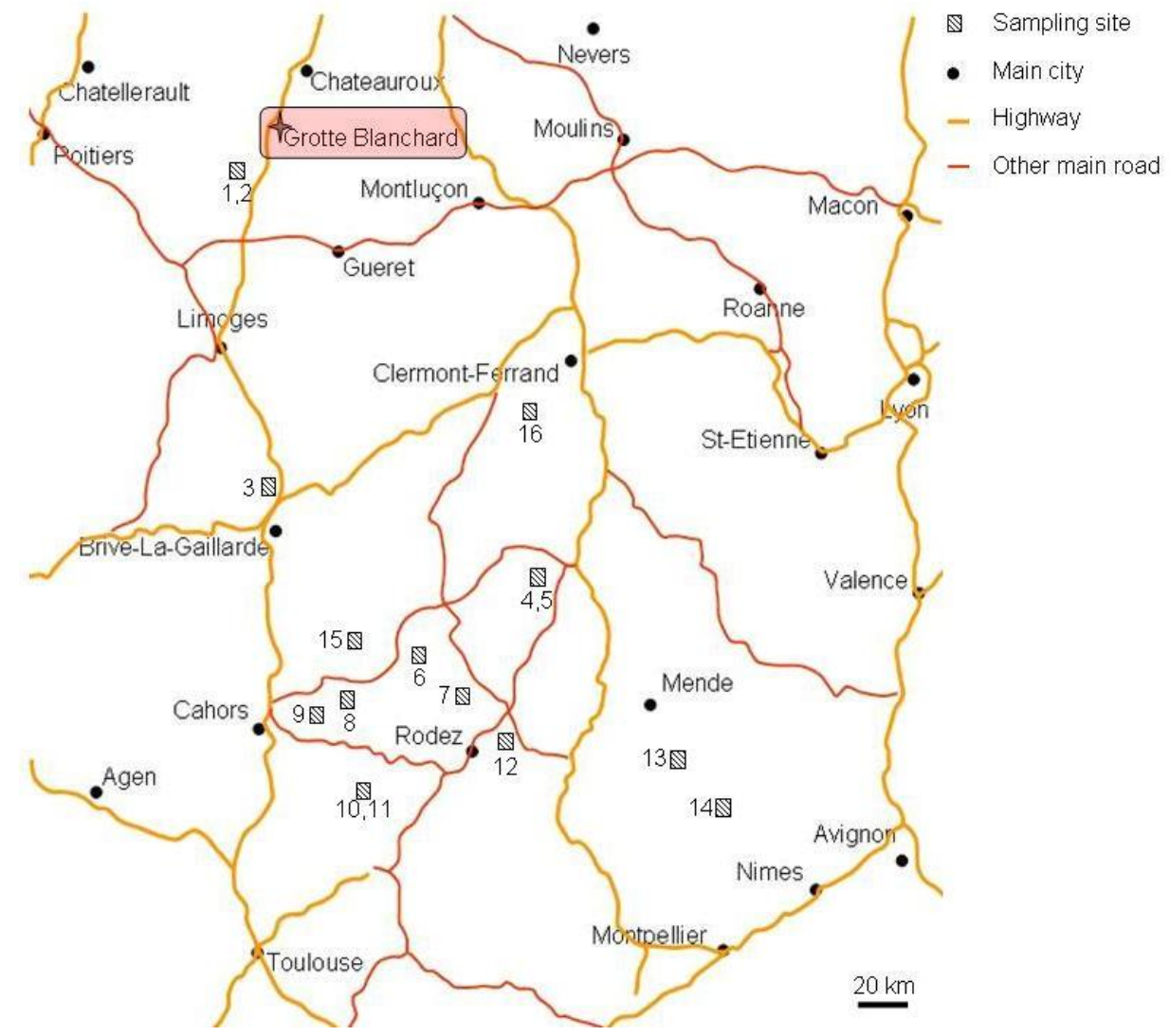


Figure 15 Rare earth elements concentration in black pigments from the pigments (dotted line) and Mn ores (see Table 1 for description)

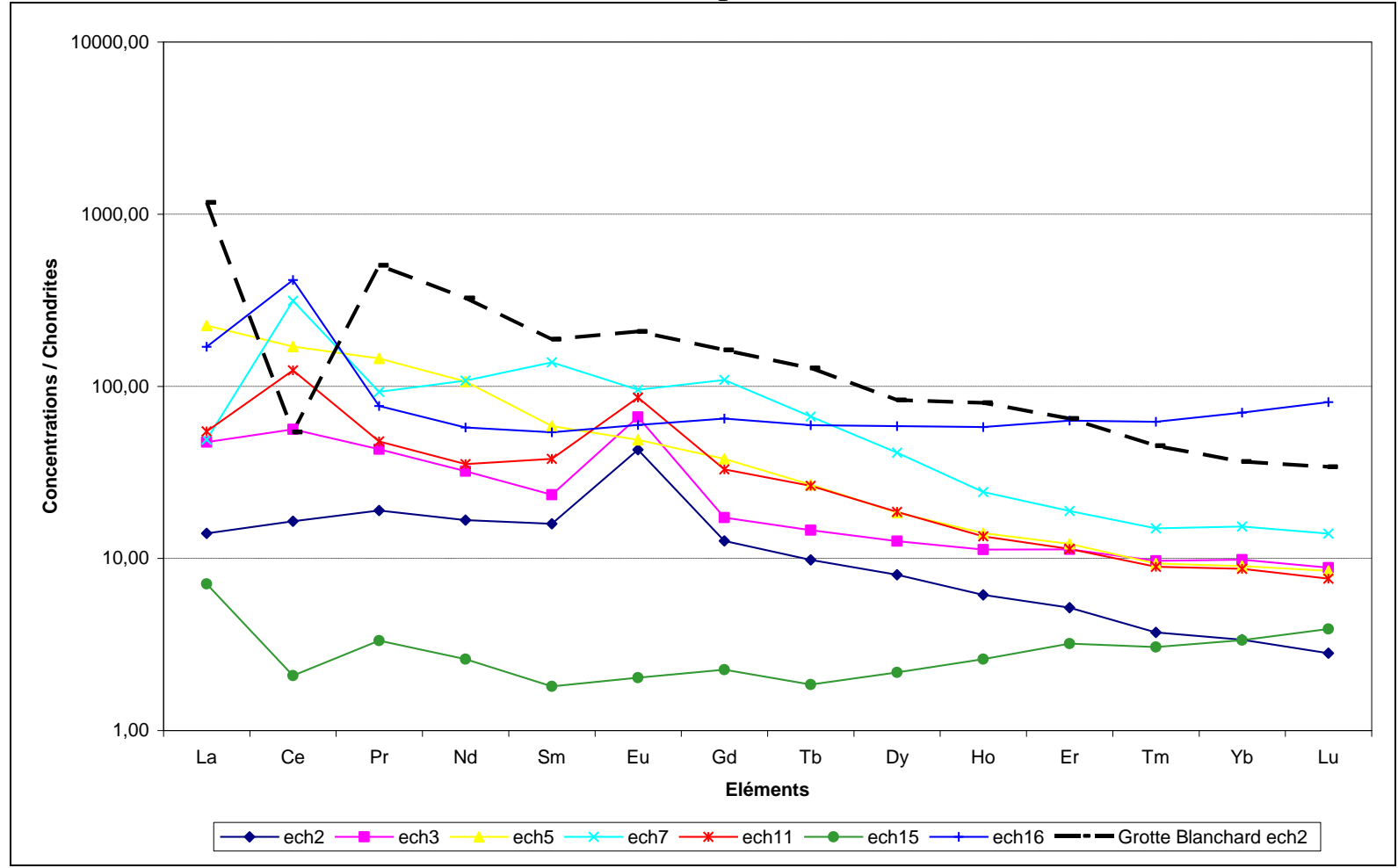


Table 1 Black pigments and Mn ores samples from Figure 14- Description of samples from Figure 15

\begin{tabular}{|c|c|}
\hline Sample & Description \\
\hline $\begin{array}{c}\text { Grotte } \\
\text { Blanchard ech2 }\end{array}$ & $\begin{array}{l}\text { black pigments at the back of the cave, on a entrocs-containing } \\
\text { limestone wall }\end{array}$ \\
\hline ech2 & $\begin{array}{l}\text { manganese oxide, Chaillac "les Redoutieres" (Indre) - Collection } \\
\text { (vein disappeared by mining) (Robert, 1972) }\end{array}$ \\
\hline ech3 & $\begin{array}{l}\text { manganese oxide, between Lascaux and Objat (Dordogne), in } \\
\text { altered schists characterized by Mn enrichment close to quartz } \\
\text { lenses }\end{array}$ \\
\hline ech5 & $\begin{array}{l}\text { manganese oxide layer (centimeter sized), } 2 \mathrm{~km} \text { south from Brezon, } \\
\text { direction of Pierrefort (Cantal), base of the volcanic flow }\end{array}$ \\
\hline ech7 & $\begin{array}{l}\text { iron, baryum and manganese veins, on the limit of an excavation, } \\
\text { Lunel "la Fage" (Aveyron), vertical pipe and crosscut near Kaymar } \\
\text { mines, South from La Fage }\end{array}$ \\
\hline ech11 & $\begin{array}{l}\text { Cournus vein : centimetric bed of psilomelane in quartz matrix, } \\
\text { within metamorphic rocks (gneiss, schists), La Fouillade (Aveyron) }\end{array}$ \\
\hline ech15 & $\begin{array}{l}\text { Crusted psilomelane vein in fractures, Ste Colombe "La Vitarelle" } \\
\text { Road D76 close to Bouxal (Lot) }\end{array}$ \\
\hline ech16 & $\begin{array}{l}\text { Superficial manganese oxide deposits on pyroclastic flow, south of } \\
\text { the Guery lake (Puy de Dôme) }\end{array}$ \\
\hline
\end{tabular}

For samples ech2 to ech16, see Figure 14 